\title{
OS REPUBLICANOS E A ABOLIÇÃO
}

\author{
Maria Fernanda Lombardi Fernandes
}

\begin{abstract}
RESUMO
O presente trabalho discute a relação existente entre os republicanos e a idéia de abolição da escravidão. Os republicanos não formavam um bloco monolítico; republicanos como Luís Gama e Silva Jardim, por exemplo, não dissociavam a luta pela República da luta pela Abolição, diferentemente dos republicanos fazendeiros que, se não lutavam contra a Abolição diretamente, não se empenhavam na sua efetivação. Aos republicanos mais "radicais", que buscavam associar as duas lutas, restou o rompimento com o movimento republicano oficial - casos de Patrocínio e Gama - ou a conivência com os republicanos senhores de terras e escravos - caso de Silva Jardim. As cisões no campo mais radical do movimento republicano contribuíram para o fortalecimento de um grupo republicano mais "moderado", ou mesmo "conservador", que se tornou a face dominante do republicanismo brasileiro. Nossa hipótese central é de que o tratamento dado à questão da Abolição foi fundamental na formatação que a República teve no Brasil.
\end{abstract}

PALAVRAS-CHAVE: escravidão; abolicionismo; republicanismo.

\begin{abstract}
"Chegam a ter graça, realmente, os nossos antagonistas! Antigamente acusavam a alguns dos nossos correligionários porque possuíam escravos, e declaravam-se republicanos. Ofato de ter escravos impedia, segundo eles, que um cidadão pudesse fazer parte dos nossos arraiais. Eis que, abolida a escravidão, os lavradores, por isso mesmo que não tinham mais escravos, declararam-se republicanos; nova censura! Acusados por, tendo escravos, serem republicanos; acusados por serem republicanos, depois que não têm escravos!' (Silva Jardim, Memórias e Viagens).
\end{abstract}

\section{O LONGO CAMINHO DAABOLIÇÃO}

A partir de 1870, dois temas ganharam a ponta do cenário nacional: as questões abolicionista e republicana. Não passaria um dia sequer na imprensa e na vida intelectual brasileira sem que um ou os dois fossem discutidos acaloradamente. Não era possível passar ao largo da discussão e não tomar posição frente às idéias debatidas.

Em outros períodos da história brasileira as questões da Abolição e da República foram levantadas, mas em nenhum momento o debate dessas idéias tornava-se tão importante como naquele momento. As questões centrais para o país também tornaram-se questões centrais para toda uma geração que entrava em cena na década de $1870 \mathrm{e}$ que seria responsável pela condução dos rumos políticos do país no último quartel do século XIX, a chamada geração de 1870 (ALONSO, 2000).

Para esta geração, a grande questão que se colocava era a articulação entre os ideais abolicionista e republicano. É em torno dessa dupla que se dão as clivagens entre os membros do movimento de contestação ${ }^{1}$. Não necessariamente as bandeiras eram carregadas conjuntamente pelos homens da época. Era plenamente possível ser republicano e defender, se não a escravidão, a

\footnotetext{
${ }^{1}$ Sem dúvida, as questões mais relevantes eram a Abolição e a República, mas não só. Antes da República propriamente dita, estava em jogo o questionamento da excessiva centralização promovida pelo Império. Nesse sentido, as divisões remontam aos liberais e conservadores, com as demandas por descentralização fazendo parte do ideário liberal, às vezes mais enfatizado, às vezes menos, dependendo da proximidade do poder ou mesmo da facção em pauta. Não são poucas as análises que vinculam o nascimento do republicanismo a partir de 1870 com uma constatação de inefetividade das demandas liberais dentro do Império. Segundo Sérgio Buarque de Holanda, "foram os republicanos os que, retomando a bandeira caída por terra, se dispuseram a levar às conseqüências últimas os princípios que outrora tiveram em comum com os liberais genuínos" (HOLANDA, 1985, p. 261).
} 
protelação da abolição; ao mesmo tempo em que era possível defender o fim da escravidão, sem mais delongas, e a manutenção da Monarquia. Várias posições intermediárias também eram possíveis. Isso gerava a cisão entre o grupo de contestadores em dezenas ou centenas de associações, clubes, organizações políticas ou de ação social etc. Em torno desses dois temas também eram construídas as alianças - temporárias ou definitivas - entre membros a princípio pertencentes a correntes antagônicas, como no caso da aliança entre os "novos liberais" e os "positivistas abolicionistas" (idem).

A questão abolicionista ganha fôlego no Brasil a partir da década de $1870 \mathrm{com}$ o fim da Guerra do Paraguai, mas a campanha de fato explode na década de 1880 com a multiplicação dos quilombos e da ação dos caifazes, e com a propaganda propriamente dita, nas cidades e na imprensa do país.

Entre 1885 e 1888 cresceu de maneira vertiginosa o movimento agora abolicionista (e não simplesmente emancipacionista). A mudança de posição de figuras-chave como Antônio $\operatorname{Prado}^{2}$ demonstrava claramente que a abolição era uma questão de curtíssimo prazo. Além do movimento dos escravos propriamente dito, crescia, inclusive dentro do Poder Judiciário, a aversão à manutenção da escravidão. Cada vez mais, decisões judiciais eram baseadas na lei de 1831 que estabelecia a proibição do tráfico de escravos. Os advogados alegavam e os juízes acatavam a ilegalidade da escravidão daqueles descendentes de escravos que haviam entrado no país após 1831,

\footnotetext{
2 Antonio Prado era um dos principais líderes e portavozes do Partido Conservador em São Paulo e tradicional opositor de medidas emancipacionistas. Segundo Kugelmas, "só quando se assegurou definitivamente a corrente migratória subsidiada em 1886, o desinteresse pela sorte da escravidão levou à mudança de atitude de Antonio Prado, então ministro do gabinete Cotegipe e um dos principais líderes do Partido Conservador, que, nas palavras insuspeitas de Nabuco, 'levantou o veto de São Paulo à abolição"' (KUGELMAS, 1986, p. 17). Ainda ministro da Agricultura de Cotegipe, Prado distancia-se deste e passa a empreender uma aproximação com setores abolicionistas, admitindo a inevitabilidade da abolição. A postura de Prado, contraposta a de um "emperrado" como Cotegipe, é analisada por Kugelmas (idem, p. 34-37). Devemos lembrar, ainda, que Antonio Prado foi ministro também do gabinete João Alfredo, que promoveu a abolição, e foi autor de um projeto de lei, por São Paulo, que previa a libertação final dos escravos, mas num prazo mais dilatado.
}

portanto, via contrabando. Estabeleciam-se previsões de que não haveria possibilidade de manter-se a escravidão para além de 1890, vista como data-limite. Em torno desse fato é que as discussões parlamentares se orientaram.

Em março de 1888 chega ao poder o gabinete de João Alfredo, conservador, mas antagonista do grande chefe fluminense Paulino Soares de Sousa e do Barão de Cotegipe. O gabinete João Alfredo torna-se o responsável pela aprovação da lei Áurea e agrava a crise partidária entre conservadores e liberais. Enfrenta ferrenha oposição de alguns membros de seu partido, mas encontra apoio em liberais do calibre de Joaquim Nabuco. Este, de maneira perspicaz, já havia demonstrado a pouca importância que a distinção partidária fazia nessa questão: "Nós nos achamos à beira da catadupa dos destinos nacionais e junto dela, é tão impossível ouvir a voz dos partidos, como seria impossível perceber os zumbidos dos insetos atordoados que atravessam as quedas do Niágara. [...] Discutir se é o Partido Liberal ou o Partido Conservador que tem direito de fazer esta reforma, é cair sob o rigor de uma etiqueta constitucional muito pior que esta etiqueta monárquica que fazia um rei de Espanha morrer sufocado, por não se achar perto o camarista que tinha direito de tocar no braseiro" (Nabuco apud MORAES, 1986, p. 267-268).

João Alfredo havia passado por uma evolução, nos dizeres de Evaristo de Moraes. Assim como Antônio Prado e Ferreira Viana, havia abandonado a postura de 1871 (contrária à Lei do Ventre Livre) e aderido à causa emancipacionista (mas não necessariamente abolicionista, isto é, da emancipação sem cláusulas). O movimento abolicionista, mesmo assim, fez de João Alfredo um ícone e passou a sustentá-lo politicamente. Em abril de 1888 o parlamento recebia, vindo de São Paulo, o projeto de libertação dos escravos de autoria de Antônio Prado. Pelo projeto, o espírito da indenização mantinha-se, já que os escravos libertados deveriam permanecer em seus postos ao menos por dois anos recebendo "módica retribuição" (MORAES, 1986, p. 264). No entanto, não foi esse o projeto que foi colocado em votação. Como argumentava o Barão do Rio Branco, o projeto tardou: uma lei que estendesse a escravidão por dois ou mais anos teria sido bemvinda em 1886, mas já não era suficiente em 1888. Assim, em 8 de maio de 1888 apresentava-se o projeto de Rodrigo Silva, em nome da Princesa Isabel, que se tornaria a Lei Áurea: a abolição da 
escravidão em todo o território nacional, sem cláusula de indenização.

A resistência conservadora na Câmara articulava-se em torno do núcleo fluminense, em que se destacava Andrade Figueira. Os vaticínios dos conservadores apontavam para a catástrofe que se abateria sobre o país e sobre a desorganização da produção. Alguns deputados, como o paulista Pedro Luís Soares de Sousa, levantaram a questão da indenização, mas já era tarde. $\mathrm{O}$ projeto foi aprovado na Câmara por 85 votos contra 9 , sendo 7 destes oriundos de representantes do Vale do Paraíba fluminense.

A lei foi promulgada em 13 de maio de 1888, mas muitos conservadores (e também liberais) não abandonaram a idéia de indenização. Pelo contrário, levaram sua insatisfação para o Parlamento e pugnaram por medidas que viessem a "salvar a lavoura" mesmo no regime republicano, que se instalaria um ano e meio depois. Qual era o argumento básico? Em suma, a questão da propriedade. Resumidamente, Cotegipe expõe a idéia do grupo: "enfim, decreta-se que, neste país, não há propriedade, que tudo pode ser destruído por meio de uma lei sem atenção nem a direitos adquiridos, nem a inconvenientes futuros" (Cotegipe apud MORAES, p. 277).

O que a abolição feriu foi o sagrado direito de propriedade. Sendo o escravo um bem, é justo que haja indenização ao seu proprietário quando este bem é tomado pelo Estado, que foi o que ocorreu com a libertação de maio de 1888. Mas, a questão era bastante espinhosa. Como sustentar argumentos liberais em nome da indenização e ao mesmo tempo negar a liberdade aos escravos? Essa é uma longa questão no Brasil que remonta ao período colonial, mas, mais ainda, ao período imediatamente posterior à independência, quando a escravidão deixou de ser uma imposição do sistema colonial e passou a ser uma questão da jovem nação independente. Apesar da argumentação desenvolvida em termos de direitos individuais como o direito à propriedade - tanto a defesa da escravidão quanto da abolição deu-se no Brasil em termos muito mais da chamada razão nacional, e foi dessa maneira que a questão da liberdade e da propriedade foi equacionada ${ }^{3}$.

\footnotetext{
3 Hebe Mattos afirma que havia uma voz dissonante ainda na década de 1830. Tratava-se do Conselheiro Antonio Rebouças, que destoava da tradição liberal brasileira ao
}

De maneira geral, o movimento abolicionista brasileiro não foi marcado pela defesa dos direitos individuais dos escravos. Essa seria uma tradição liberal anglo-saxônica. Grosso modo, a defesa da abolição no Brasil apoiou-se em argumentos de outra espécie, baseados na razão nacional: a escravidão era um cancro - mesmo nos dizeres de conservadores - por ser responsável pela não construção da nação. A escravidão fazia mal a senhores e a escravos e impossibilitava a formação de cidadãos no país. Como aponta Carvalho: "Fora do campo religioso, o principal argumento que se apresentava no Brasil em favor da abolição era o que podíamos chamar de razão nacional, em oposição à razão individual dos casos europeu e norte-americano. A razão nacional foi usada por José Bonifácio, que dizia ser a escravidão obstáculo à formação de uma verdadeira nação, pois mantinha parcela da população subjugada a outra parcela, como inimigas entre si. Para ele, a escravidão impedia a integração social e política do país e a formação de forças armadas poderosas. Dizia, como fez também Joaquim Nabuco, que a escravidão bloqueava o desenvolvimento das classes sociais e do mercado de trabalho, causava o crescimento exagerado do Estado e do número de funcionários públicos, falseava o governo representativo" (CARVALHO, 2001, p. 50-51).

A percepção da escravidão como um entrave à formação do país e do povo brasileiro não era nova. Estava na pauta de uma ampla parcela dos liberais desde a independência. Já o patriarca José Bonifácio de Andrada e Silva havia levantado a

reconhecer apenas o direito de propriedade como base da escravidão. Findo este, o liberto deveria automaticamente adquirir a cidadania. A oposição estabelecida por ele era entre cidadão e escravo e não havia possibilidade de "racializar" a questão para além da libertação do escravo. No entanto, a abolição não era um horizonte próximo, nem estava na ordem do dia. No seu modelo, a emancipação viria como solução individual amparada em lei: o principio embutido na lei de 1871 - a compra da liberdade - era defendida por ele ainda nas décadas de 1840 e 1850: "Do seu ponto de vista, era como se, terminado o tráfico, que produzia novos escravos, e garantido o direito à auto-compra, a obra da emancipação, no melhor estilo liberal, pudesse ser lentamente deixada a cargo das 'virtudes e talentos' dos próprios escravos" (MATTOS, 2004, p. 52-53). Da mesma maneira, segundo Mattos, Luís Gama, bem mais novo que Antônio Rebouças, também se filiava ao liberalismo na defesa das liberdades dos escravos e dos libertos, mas, em sua época, a questão da abolição já estava posta, diferentemente da época do Conselheiro Rebouças. 
questão (COSTA, 1999; SILVA, 1999). Mas, naquele momento, mesmo os críticos da escravidão não viam a possibilidade de manter-se a unidade do jovem país sem a instituição da escravidão. Também os proprietários de escravos defendiam a escravidão em termos de razão nacional. Não era possível organizar a lavoura do país sem o recurso à escravidão. Havia o argumento liberal da propriedade, mas este era de menor importância, ao menos até 1850 .

A partir de 1870 a discussão ganha corpo. Mesmo os fazendeiros que dependiam da escravidão e defendiam a sua manutenção olhavam com desconfiança cada vez maior para as senzalas. A despeito da melhoria no tratamento dos cativos após 1850 - possivelmente pelo encarecimento do escravo com o fim do tráfico, ocorre um progressivo aumento das rebeliões de negros, notadamente no Vale do Paraíba e no Oeste Paulista, sendo esta última região vista como particularmente perigosa e violenta: "[...] as áreas cafeeiras do Oeste Paulista surgiam, neste contexto, como particularmente violentas. Tendo recebido um influxo de mão-de-obra não desprezível ao longo dos anos 70, alguns historiadores argumentaram que seria o impacto da massa de escravos recém-chegados, desenraizados, o fator explicativo do incremento das taxas de criminalidades nesta região" (MACHADO, 1994, p. 24).

A situação, que era grave, tendia a piorar com o fim da lei dos açoites, de $1886^{4}$. De fato, sem o amparo da repressão, como manter as senzalas em paz, se também as cidades estimulavam a rebelião dos negros? A luta dos senhores em defesa da escravidão voltou-se fundamentalmente para a

\footnotetext{
${ }^{4}$ A lei dos açoites, revogada em 1886, estabelecia o direito dos senhores punirem seus escravos com castigos físicos. Com a sua revogação, muitos fazendeiros revoltaram-se, como mostra Machado: "[...] a revogação apenas tardia da pena de açoites em 1886, após longa batalha de propaganda abolicionista, ocasionou ferozes protestos dos fazendeiros, convencidos, e não sem razão, que suprimi-la seria o mesmo que abolir a escravidão. Pois, como havia notado o Barão do Bom Retiro, muitos anos antes, por ocasião do debate sobre a proposta do Conselheiro Nabuco sobre a revogação do artigo 60 , a substituição desta pela prisão com trabalhos, se aplicada a escravos, tornar-se-ia um estímulo ao crime, uma vez que seria a mesma, por muitos, percebida como um melhoramento de sua condição" (MACHADO, 1994, p. 24).
}

questão da indenização. Era com argumentos de defesa do direito à propriedade que a escravidão era sustentada. Porém, também esse aspecto os abolicionistas questionavam: como era possível apoiar-se no argumento liberal da defesa da propriedade se esta era formada por seres humanos? Mais ainda, os advogados abolicionistas buscaram na argumentação dos senhores a possibilidade de questionar de maneira mais ampla o próprio direito de propriedade: aceitando a idéia de que o direito de propriedade era justo, o que esses advogados questionavam era a própria legalidade da propriedade reclamada pelos senhores. A grande maioria dos escravos que os senhores alegavam possuir e pelos quais buscavam ser indenizados eram ilegais, já que eram filhos de africanos que entraram no Brasil após 1831, portanto, em contrariedade à lei ${ }^{5}$. Como bem aponta Machado (1994), a única forma de se justificar o direito de propriedade do senhor era apelar para a própria situação do escravo. Ou seja, a condição de escravo justificava a posse por parte do senhor da mercadoria, o que começava a ser questionado com força cada vez maior nos tribunais pelos advogados abolicionistas.

A luta pela indenização e a defesa do direito de propriedade por parte de senhores arruinados continuou para além da abolição. Diferentemente do que pregavam os apocalípticos, não houve a sublevação da ordem e a destruição da lavoura no país, o que não quer dizer que muitos fazendeiros não tenham sofrido com o fim "abrupto" da escravidão. As demandas por algum tipo de indeni-

\footnotetext{
5 Apesar de a Lei Eusébio de Queirós ser de 1850, devemos remeter aqui à lei anterior, de 1831, fruto de acordos com a Inglaterra. Luiz Felipe de Alencastro chama a atenção para o significado da lei de 1831: "sur le plan juridique, la loi de 1831 interdissant la traite au Brésil laissait prévaloir une situation ambiguë dans la mesure où ce texte stipulait aussi que les esclaves introduits après cette date seraint considérés comme étant affranchis. De ce fait, les propriétaires de 500000 esclaves introduits après 1831 n'avaient pas leur droite de propriété totalement assuré. Ils pouvaient en outre être condamnés au titre de l'article 179 du code criminel de 1830 qui punissait la mise en esclavage de personnes libres. Les sénateurs brésiliens s'étaient aperçus des dangers que cette loi laissait subsister et avaient demandé la suppression de ce texte dès 1837 . toutefois, une telle mesure aurait constitué une rupture des traités anglo-brésiliens. On a donc mantenu la loi de 1831 tout en ne l'observant pas" (ALENCASTRO, 1979, p. 412).
} 
zação estenderam-se até o novo regime republicano, o que explica, de alguma maneira, a afluência de escravistas ao Partido Republicano a partir do 13 de Maio. Porém, assim como a Monarquia não havia atendido aos apelos desses proprietários, também o novo regime não contemplou sua reivindicação ${ }^{6}$.

O novo regime nasceu sem o problema da escravidão e esquivou-se de debater a indenização. Argumentava-se que a questão da indenização era da Monarquia e que o novo regime não poderia arcar com os erros do passado. Dessa maneira, perderam novamente os defensores da indenização que, nos últimos momentos, depositaram no novo regime a esperança do ressarcimento. Apesar de frustrados, muitos haviam acreditado que a República poderia resolver a questão de maneira satisfatória. Ora, por que esses homens acreditaram nisso? Haveria algum indicativo de que o novo regime seria sensível a essas demandas? Para entendermos um pouco melhor essa questão, faz-se necessário analisar a relação entre os republicanos e a abolição, relação essa que não foi simples nem única.

\section{OS REPUBLICANOS E A ABOLIÇÃO}

Os últimos anos que precedem a abolição definitiva em 1888 são bastante tumultuados e marcam uma série de cisões no movimento abolicionista e na sua relação com o republicanismo. A questão em pauta é a precedência da República ou da Abolição como objetivos a serem alcançados. Muitos dos membros da geração de 1870 não dissociam uma da outra, como é o caso de Silva Jardim, um dos mais importantes propagandistas republicanos. Na prática, porém, dividem-se quanto às prioridades. A cisão definitiva opera-se após o 13 de Maio e, nesse sentido, é emblemático o rompimento entre José do Patrocínio e Silva Jardim (QUEIROZ, 1967; LIMA, 1987; CARVALHO, 1996; FERNANDES, 2004), desde então inimigos figadais e, curiosamente, ambos desprezados pelo novo regime em suas primeiras horas.

A Lei Áurea torna-se um divisor de águas no movimento republicano, com a inserção de ele-

\footnotetext{
6 Devemos lembrar a atitude de Rui Barbosa ao ordenar a queima dos arquivos que atestavam a propriedade de escravos, ainda no governo provisório, numa tentativa de cessar o movimento de luta por indenização no novo regime. Ver Lacombe, Siva e Barbosa (1988).
}

mentos alheios à história do movimento - aqueles a quem Patrocínio denominou "republicanos do 14 de maio", muitos deles membros egressos das fileiras do Partido Conservador. A ação da Coroa em empreender a abolição destruiu seus alicerces e provocou rupturas definitivas no próprio movimento republicano: "Os partidos Liberal, Conservador e Republicano estavam de fato divididos frente à questão da abolição; a lei da eleição direta cassara de fato o voto a milhares de brasileiros, dando maior consistência à Câmara, mas afastando-a da opinião pública; o Poder Moderador tornara-se nesta conjuntura de fato ambíguo: seu exercício poderia ser formalmente ditatorial, mas estar, ao mesmo tempo, mais próximo da opinião pública. Neste sentido, a batalha da abolição corroeu a base dos partidos nacionais e contribuiu não só para o fim da monarquia como para a proclamação da república manu militari. Culpa dos abolicionistas? Sem dúvida, não. O sistema representativo é que não funcionava adequadamente" (CARVALHO, 1996, p. 15).

O Partido Republicano foi fundado em 1870 no Rio de Janeiro, mas não logrou controlar os diversos "filhotes" nascidos nas províncias. Mesmo assim, consistia em uma novidade em relação a movimentos anteriores. Como afirma Sérgio B. de Holanda, "tradicionalmente a idéia republicana tinha sido inseparável, no país, e desde antes da Independência, de manifestações explosivas contra o poder constituído. Além disso, tivera invariavelmente cunho regional, e se pretendesse abarcar o país inteiro, deveria fazê-lo partindo da periferia para o centro. Agora, e é a outra novidade, ela surge no centro, na Corte, de onde irão irradiar-se, não apenas os seus princípios, mas ainda as normas de ação comum, para as diferentes províncias" (HOLANDA, 1985, p. 261).

A fundação desse partido dava-se em meio à crise gerada pela queda do gabinete Zacarias em 1868 e à insatisfação liberal ${ }^{7}$. Na época, vários clubes radicais foram fundados.

\footnotetext{
7 A queda do Gabinete Zacarias marca o fim do período conhecido como Conciliação. Desde 1862 uma quebra do Partido Conservador, que deu origem à Liga Progressista, acabou gerando o fenômeno de dois partidos liberais: os históricos e os "ligueiros". A volta dos conservadores mais "duros" com Itaboraí foi decisiva para o rompimento de parte dos liberais com a ordem monárquica, favorecendo a formação do Partido Republicano. Campos Sales, em suas memórias, atenta para a importância do fato, ao analisar a
} 
Os primeiros anos são bastante difíceis para o novo partido. A partir de 1875 , ocorre uma nova aproximação entre os liberais e o governo, o que causou a defecção de muitos membros do Partido Republicano que voltaram ao partido de origem. A situação agrava-se a partir de 1878. Campos Sales dá-nos mostra do problema gerado pelo Gabinete Sinimbu para as hostes do Partido Republicano: "A situação liberal, inaugurada em 1878 pelo Gabinete de 5 de janeiro, veio pôr à prova a sinceridade e a firmeza dos republicanos. [...] O surpreendente acontecimento impressionou de alguma sorte o espírito público, chegando-se a sentir, sobretudo em determinadas regiões do país, um movimento de adesão, que levou o alarma ao campo dos propagandistas" (CAMPOS SALES, 1983, p. 14). Esse já não foi o caso em São Paulo. Apesar de algumas defecções, o PRP continuou mais bem estruturado do que o partido nacional. Em São Paulo, paradoxalmente, onde o Partido Liberal tinha deitado raízes mais fortes, aparentemente o ideal republicano federalista tinhase fincado de maneira mais sólida do que na Corte, ou mesmo na província do Rio, onde o Partido Liberal era bem menos atuante do que o Partido Conservador. Além disso, em São Paulo, a direção do PRP havia tomado uma posição de força, impedindo as defecções, com Campos Sales à frente, chamando os republicanos paulistas para atentarem para os ardis do governo e para a impossibilidade de transformações serem efetuadas sob a égide da Monarquia. Como resultado, "em São Paulo não ocorrem defecções e o republicanismo paulista pesa cada vez mais no conjunto nacional" (KUGELMAS, 1986, p. 32). Além disso, em São Paulo era clara a aproximação dos republicanos e conservadores, ambos na oposição. O rompimento foi bastante positivo para o PRP, já que livrava os republicanos de uma posição de subordinação em relação ao Partido Libe-

conjuntura de 1868, primeiramente com a organização do Partido Radical e, posteriormente, com o PR: "Do seio do Partido Histórico, que combatera a Liga Progressista, foi que, em 1868, se desprenderam os elementos políticos que então levantaram o programa radical, como um primeiro passo, definitivo, para o Partido Republicano, por eles próprios organizado em 1870. Este partido surgia, zeloso de sua autonomia nas lutas políticas, sem aproximações nem afinidades com os velhos partidos monárquicos, visto que tinha por objetivo não mais uma simples missão reformadora, mas a transformação fundamental do regime" (CAMPOS SALES, 1983, p. 13). ral. De acordo com Sérgio B. de Holanda, "as vantagens que tirariam os republicanos das alianças com os conservadores vinham sobretudo de poderem agir com maior independência, uma vez eleitos" (HOLANDA, 1985, p. 264).

Em termos doutrinários, o Partido Republicano levanta a bandeira da descentralização e do federalismo, opondo-se ao centralismo monárquico que sufocava as províncias. Devemos lembrar que a defesa do federalismo, por si só, não representava um ataque à Monarquia. Liberais como Rui Barbosa acreditavam na eficácia de uma monarquia federativa e abandonaram a primeira quando as reformas que visavam à descentralização mostraram-se ineficazes. Mas, como chama a atenção Sérgio B. de Holanda, "os que preconizavam essa espécie nova, ainda quando não fossem republicanos, já se situavam na franja do republicanismo, e Rui Barbosa falava mesmo na federação como um meio de republicanizar a monarquia" (idem, p. 269).

O grau de defesa do federalismo, no entanto, variava de acordo com a província em que se organizava o partido. Claramente mais forte em São Paulo e no Rio Grande do Sul, o federalismo não tinha cores tão fortes na província do Rio de Janeiro e na Corte, mas ainda era a principal bandeira do partido. Todos os males pelos quais passava o país eram identificados com a excessiva centralização operada pela Monarquia: os republicanos de 1870 chamavam a atenção, inclusive, para o risco de desmembramento que o país corria com a manutenção do regime centralizador ${ }^{8}$. A República era encarada como o regime do mundo moderno e americana por excelência: a Monarquia era européia e anacrônica, planta exótica em solo americano.

A adoção de uma linha "evolucionista" e gradual para a implantação do novo regime coadunase com o caráter reformista desta elite contestadora (ALONSO, 2000). A República seria questão de tempo, a Monarquia cairia de podre: restaria aos "republicanos comportados" (KUGELMAS, 1986, p. 32) esperar para implementar seu programa. Alguns membros, no

\footnotetext{
8 "Se carecêssemos de uma fórmula para assinalar perante a consciência nacional os efeitos de um e outro regime, nós a resumiríamos assim:-Centralização-Desmembramento. Descentralização - Unidade" (Manifesto do Partido Republicano apud PESSOA, 1973, p. 56; grifos no original).
} 
entanto, apelavam para a bandeira da revolução como forma de chegar-se ao poder, o que foi o caso de Silva Jardim, em famosa querela com Quintino Bocaiúva quando da disputa pela direção do partido, mas esta era uma posição claramente minoritária.

O recurso ao golpe militar partiu justamente desta corrente hegemônica, que via a implantação da República como algo gradual. O apelo ao Exército, no entanto, deu-se por meio da cooptação da alta cúpula para o movimento, visando impedir uma quebra de hierarquia - e o potencial revolucionário que adviria dessa quebra - que ocorreria se se recorresse aos baixos oficiais, entre os quais o ideal republicano já estava disseminado9 .

A própria estrutura do partido, dividido em seções provinciais que, na verdade, funcionavam como células autônomas, dificultava uma linha de ação única para seus membros. Várias foram as tentativas de organização de um partido em nível nacional, mas elas acabaram enfrentando a grande particularidade do movimento nas províncias e o peso desigual que possuía o Partido Republicano Paulista na agremiação nacional ${ }^{10}$.

O texto do Manifesto de fundação do PRP, na Convenção de Itu, em 1873, diferentemente do texto de 1870, aborda a questão da abolição. Esta é apresentada como um problema social que deveria ser resolvido pela Monarquia, que o criou e que ainda era o regime vigente. Os republicanos argumentam que a solução virá antes da República e que não devem ser cobrados por isso. Afirmam categoricamente que qualquer posição mais radical levaria à perda de membros importantes do partido - de um ou de outro lado: "Fique portanto bem firmado que o Partido Republicano, tal como consideramos, capaz de fazer a felicidade do Brasil, quanto à questão do estado servil, fita

\footnotetext{
9 A penetração do ideal republicano no Exército já vinha acontecendo havia algum tempo, seja pelos conflitos ocorridos entre a instituição e a Monarquia, seja pela penetração das idéias positivistas na corporação, que geralmente é imputada a Benjamin Constant ou aos jovens oficiais (BOEHRER, 1954; CASTRO, 1995).

10 A busca da construção de uma agremiação nacional vai prosseguir já no regime republicano. Durante o governo de Floriano Peixoto, Francisco Glicério empreende uma tentativa de construção do Partido Republicano Federal, mas, já durante o governo Prudente de Morais, o partido é esvaziado em detrimento dos partidos estaduais.
}

desassombrado o futuro, confiando na índole do povo e nos meios de educação, os quais unidos ao todo harmônico de suas reformas e de seu modo de ser hão de facilitar-lhe a solução mais justa, mais prática e moderada, selada com o cunho da vontade nacional. Parece que esta declaração seria suficiente para apagar todas as dúvidas. A questão não nos pertence exclusivamente porque é social e não política: está no domínio da opinião nacional e é de todos os partidos, e dos monarquistas mais do que nossa, porque compete aos que estão na posse do poder, ou aos que pretendem apanhá-lo amanhã, estabelecer os meios de seu desfecho prático. E se os nossos contrários políticos pressagiam para um futuro demasiadamente remoto o estabelecimento, no país, do sistema governamental que pretendemos, o que vem interpelar-nos hoje e desde já sobre esses meios?" (Manifesto do Congresso do Partido Republicano Paulista apud PESSOA, 1973, p. 65).

Mais ainda, se fosse instituída a República antes da resolução da questão do elemento servil, esta se daria de maneira conciliatória, mantendose, inclusive, o princípio da indenização: "Desde seus inícios, o PRP demonstrou preocupação em não perder suas bases de apoio rural em razão do problema da escravidão; sua forma de colocar o tema foi denominada por Joseph Love, como 'política de ambigüidade deliberada'. A argumentação utilizada, apesar do evidente oportunismo, não é despida de interesse; o PRP apresentava-se como favorável a uma solução pacífica e evolutiva da 'questão servil', apresentava-a como um 'fato social', que transcendia a arena políticoinstitucional onde se movia o republicanismo e atribuía a eventual solução do problema aos dois partidos monárquicos" (KUGELMAS, 1986, p. $31)$.

A postura ambígua dos republicanos em relação à abolição da escravidão só é rompida às vésperas da Lei Áurea. Até então, predominava uma linha "neutra", buscando separar os dois problemas: a República seria o regime do futuro do país e a escravidão era o regime de trabalho do passado, instituído pela Monarquia. Não era responsabilidade dos republicanos, mas, por outro lado, reconhecia-se a importância da escravidão para o funcionamento da economia do país. Observe-se que boa parte dos republicanos não via com bons olhos um rompimento abrupto do regime de trabalho - ou seja, a abolição imediata sem indenização. Além disso, fiéis ao princípio federalista, desde 
seu manifesto, em 1873, os republicanos paulistas viam a questão da abolição como devendo ser levada pelos diferentes interesses das províncias. Sob a liderança de Francisco Glicério, alegavam que "cada província deveria realizar a reforma de acordo com seus interesses peculiares, mais ou menos lentamente, conforme a maior ou menor facilidade na substituição do trabalho escravo pelo trabalho livre [...]" (Glicério apud SANTOS, 1942, p. 236).

Também os republicanos adotavam um argumento que tinha por base a não interferência do Estado em assuntos econômicos. Eram eles, entre outros, que defendiam a emancipação dos escravos pela via privada, ou seja, acreditavam que a melhor forma de se colocar fim à escravidão seria a libertação dos escravos pelos seus senhores: não foi de outra forma que se adotou essa prática em congresso do partido, já às vésperas de 1888 , quando a circular de Campos Sales aconselhando os republicanos a libertarem seus escravos acabou sendo incorporada pela direção do PRP, após a eleição de Bernardino de Campos como presidente do partido. A despeito da resistência dos fazendeiros possuidores de escravos, a indicação do líder que sempre se colocou como abolicionista foi, segundo José Maria dos Santos, uma tentativa de recuperar o partido, ofuscado pelo crescimento do movimento abolicionista. O próprio órgão de imprensa do partido - A Província de São Paulo identificava como causa do ostracismo sofrido pelo PRP, a campanha abolicionista e as posições do monarca brasileiro, francamente contrárias à manutenção da escravidão. Nesse sentido, a volta de elementos anteriormente acusados de sectarismo pela sua defesa intransigente da abolição da escravidão era fundamental para a revitalização do partido (SANTOS, 1942, p. 254-258).

Ao longo da década de 1870 operaram-se as primeiras cisões no movimento republicano que tinham como fundamento a questão da escravidão. No Rio, há o caso do rompimento de José do Patrocínio e seu grupo e, em São Paulo, de Luís Gama. A polêmica de Luís Gama com o Partido Republicano de São Paulo inicia-se já em 1873, quando este nega-se a assinar a resolução tirada na Convenção de Itu, pois o partido omitia-se na questão da escravidão. Quanto a José do Patrocínio, na convenção do partido do Rio de Janeiro, em 1881, Quintino Bocaiúva louvou os abolicionistas republicanos, mas advertiu-os por serem mais abolicionistas que republicanos, ao que Patrocínio retrucou que, se o Partido Republicano estabelecesse uma aliança com os escravocratas, eles, abolicionistas, a fariam com o Imperador (BOEHRER, 1954).

A organização do Partido Republicano no Brasil foi desigual. Desde o início, a seção paulista foi a mais estruturada e importante do país e, de alguma maneira, o PRP provocava eco sobre as demais sessões do país. Como já vimos anteriormente, o Partido Republicano nasce e cresce em íntima ligação com a fração liberal que se desencanta com o governo a partir da queda do gabinete Zacarias, em 1868. Ao final da década de 1870 , por ocasião da volta dos liberais ao poder, o partido mingua consideravelmente, mesmo que em São Paulo o esvaziamento seja menor. Em termos de representação, não há um crescimento do partido, sendo a bancada parlamentar restrita aos nomes de Prudente de Moraes e Campos Sales, pela província de São Paulo. Não se percebe um crescimento eleitoral do partido, que "patinha" ao longo da década de 1870 e mesmo de 1880.

$\mathrm{O}$ grande peso da lavoura no partido paulista se, por um lado, permitia o crescimento do movimento republicano entre a elite, por outro lado, entravava sua penetração nas camadas médias e urbanas, por associar-se aos interesses escravistas. Assim como a questão da abolição provocou fraturas nos dois partidos que sustentavam a Monarquia, abalou também o Partido Republicano. Este é, a nosso ver, uma questão central: a Monarquia, de certa maneira, moldou o Partido Republicano que se formava. Joaquim Nabuco, expoente dos chamados liberais abolicionistas, apontava para o fato de que acima dos rótulos partidários pairava a questão abolicionista, que se sobrepunha às diferenças entre liberais, conservadores e republicanos, e colocava-os misturados em campos opostos (NABUCO, 1988).

A ambigüidade mantém-se nos partidos que surgem nas várias províncias. De maneira geral, o partido republicano agrega elementos que vêem a República como necessidade primeira - anterior à abolição, portanto, e, justamente por isso, transigentes com elementos escravocratas. Com sorte, os republicanos herdariam um país sem escravos - caberia aos partidos imperiais o processo e o ônus da abolição. Esta questão provocou cisões irremediáveis em algumas províncias, como no caso de Rio e São Paulo. Já no Manifesto de 1870 
a questão da libertação dos escravos é deliberadamente omitida. No trecho que se refere à ausência de liberdade no regime monárquico, curiosamente a liberdade da pessoa do escravo não é invocada: "A liberdade de consciência nulificada por uma Igreja privilegiada; a liberdade econômica suprimida por uma legislação restritiva; a liberdade de imprensa subordinada à jurisdição de funcionários do governo; a liberdade de associação dependente do beneplácito do poder; a liberdade do ensino suprimida pela inspeção arbitrária do governo e pelo monopólio oficial; a liberdade individual sujeita à prisão preventiva, ao recrutamento, à disciplina da guarda nacional, privada da própria garantia do habeas-corpus pela limitação estabelecida, tais são praticamente as condições reais do atual sistema de governo" (Manifesto do Partido Republicano apud PESSOA, 1973, p. 47).

Como podemos perceber, para os fundadores do Partido Republicano no Brasil a questão da liberdade do escravo não se colocava como um problema de fato para o estabelecimento de um sistema mais amplo de liberdades no país, ou melhor, não era uma questão propriamente politi$c a$, daí a não necessidade de se tratar dela. Não caberia a um partido - organização fundada com o objetivo de tomar o poder e instituir uma nova ordem institucional - a tarefa de questionar o regime de trabalho adotado pelo país. Era uma bela maneira de escamotear a questão, mas isso não fugiu aos olhos dos abolicionistas, em especial aos olhos dos abolicionistas republicanos como Luiz Gama e Patrocínio, por exemplo.

Em 1887, novo congresso foi realizado. Nele reafirmavam-se as bases do documento de fundação, de 1870. No entanto, diferentemente do que ocorrera em 1870, agora o Partido Republicano colocava-se frente à questão da escravidão. É bem verdade que na lista de liberdades desejadas mais uma vez era omitida a liberdade dos homens que eram escravos. Porém, o assunto era tratado de maneira mais clara: a abolição era necessária ao desenvolvimento do país e, mais do que isso, era uma obrigação que a Monarquia havia-se furtado de resolver "de acordo com a justiça, por meio de um ato pronto e simultâneo, adotadas as precauções necessárias para evitar o abalo da propriedade mal constituída" (Manifesto do Congresso Republicano Federal apud PESSOA, 1973, p. 91). Se a Monarquia não resolveu, caberia aos republicanos esboçar uma solução bastante conservadora: propunham acabar com a escravidão em território nacional num prazo que não excedesse a data do centenário da Revolução Francesa.

A mudança de posição do partido, a adoção de uma postura mais clara em relação ao problema, coincide com o aumento do movimento abolicionista no país. Em 1887, a abolição era apenas uma questão de tempo. Não era possível aos republicanos manter a postura ambígua e o silêncio por tanto tempo. Os republicanos corriam o risco de serem surpreendidos pela abolição sem terem assumido claramente uma postura a respeito. Durante muito tempo o silêncio foi fundamental nas províncias de São Paulo e do Rio de Janeiro, onde a presença de fazendeiros ainda proprietários de escravos era bastante considerável no partido. Boehrer aponta o problema criado pela questão da abolição para o partido em São Paulo: "o Partido de São Paulo desaprovava qualquer intenção de abolir a escravidão se a vontade da nação se opusesse a uma tal emancipação. Alguns republicanos [...] desejavam a abolição imediata e violenta, não era porém justo sobrecarregar de tais planos o partido" (BOEHRER, 1954, p. 265).

Para alguns membros do Partido Republicano e do movimento republicano de maneira mais ampla, a questão da abolição sempre se fez presente. Em termos doutrinários, para homens como Bernardino de Campos, Luis Gama, Patrocínio, Rangel Pestana e Silva Jardim, entre outros, não era possível dissociar a República da abolição da escravidão. Bernardino de Campos, ao longo de seus embates com os fazendeiros escravistas do partido, argumentava que a abolição era o primeiro passo para a República e que não se deveria dissociar as duas lutas, que eram uma só. Por outro lado, boa parte do núcleo republicano que se organizara em torno de Campinas defendia a escravidão e acreditava que o Partido Republicano deveria ficar fora da discussão. Mais do que a defesa da escravidão, o que os fazendeiros paulistas defendiam era a viabilização da lavoura por intermédio do suprimento de braços e a manutenção do direito de propriedade com a idéia da indenização ${ }^{11}$.

\footnotetext{
11 Eduardo Silva afirma que, "oficialmente, o Partido Republicano defendeu sempre a idéia de indenização. Esta posição lhe valeu, nos últimos anos do Império, o apoio de muitos senhores de escravos, sobretudo depois do 13 de maio de 1888. Quando os fazendeiros do café começaram a engrossar as fileiras republicanas, Joaquim Nabuco, que
} 
Quando da discussão do projeto Dantas, modificado por Saraiva e posteriormente promulgado no gabinete Cotegipe ${ }^{12}$, o Partido Republicano mostrou claramente sua fratura. A posição de Prudente de Moraes e de Campos Sales a favor do projeto original, em que a idéia de indenização não era contemplada, levou a uma fria recepção destes parlamentares por parte de seus correligionários em São Paulo (SANTOS, 1942; CAMPOS SALES, 1983). A aprovação da Lei dos Sexagenários, nos moldes mais comedidos de Saraiva-Cotegipe, foi vista pela lavoura escravista como uma última concessão ao emancipacionismo ${ }^{13}$. Assim como em 1871, agora, com a Lei dos Sexagenários, havia a possibilidade de o escravo recorrer às instituições legalmente estabelecidas em busca de seus direitos vistos como tais pela lei. A legislação acerca da questão escravista efetuou a clivagem já anotada por Nabuco e fez com que os conflitos fossem levados para dentro dos partidos, inclusive do Partido Republicano.

A ambigüidade do Partido Republicano em relação à abolição impediu uma ação coordenada de seus membros. Cisões ocorrem antes e após o 13 de Maio. Em 1888, ainda antes da Lei Áurea, em eleições para o Senado, concorrem o republicano Quintino Bocaiúva e o conservador Ferreira Vianna (um "evoluído" em relação a 1871) ${ }^{14}$. Dada a atu-

por essa época trabalhava em O Paiz ouviu de Quintino a entusiástica narrativa: 'acabo de estar numa reunião republicana - disse ele - que representava mais de vinte mil contos"” (SILVA, E., 1986, p. 69).

12 Cotegipe acabou sendo o responsável pela aprovação final da lei dos Sexagenários (1885), mantendo o princípio da indenização embutido ao prolongar o tempo pelo qual o escravo deveria permanecer "prestando serviços" ao senhor.

13 Aparentemente, a Lei dos Sexagenários teve um alcance muito restrito. Mas importa analisá-la em conjunto com as demais leis que tratavam da questão escrava. Sidney Chalhoub, ao analisar o escravismo e o abolicionismo na Corte nos últimos anos do Império, mostra como, apesar das limitações aparentes das leis, estas foram extremamente importantes no processo de luta pela abolição. No caso específico da Lei do Ventre Livre (1871), por exemplo, houve "o reconhecimento legal de uma série de direitos que os escravos haviam adquirido pelo costume e a aceitação de alguns objetivos das lutas dos negros" (CHALHOUB, 2001, p. 159).

14 Ferreira Viana ocupou a pasta da Justiça no gabinete João Alfredo. Converteu-se tardiamente à causa abolicionista ação do último na defesa do abolicionismo, a Confederação Abolicionista orienta o voto no Partido Conservador. Republicanos históricos como José do Patrocínio e João Clapp apóiam Vianna e não o republicano Bocaiúva. Num partido com pequena densidade eleitoral, perder votos para um conservador dentro de suas próprias fileiras não era um bom sinal.

Apesar da perda de vários membros mais combativos, a causa republicana também ganhou muito em manter essa ambigüidade, principalmente após o 13 de Maio, quando viu suas fileiras inchadas por uma série de fazendeiros desiludidos com os rumos da Monarquia, os acidamente nomeados por Patrocínio de "republicanos do 14 de maio"15. Feita a abolição, todas as energias poderiam ser canalizadas para a discussão e a implantação da República, agora reforçada pela presença de membros egressos da elite imperial e descontentes com a Monarquia. Não é coincidência que as peregrinações de Silva Jardim, a despeito de seu estremecimento com a cúpula do partido, passam a fazer sucesso a partir do 13 de Maio. Como aponta Sidney F. Leite (1993), a República ganhava seu radical, que, curiosamente, receberia amplo apoio das fileiras mais conservadoras do partido: fazendeiros "desencantados" com a Monarquia e com o fim da escravidão.

O mesmo Silva Jardim teve participação no episódio decisivo da adesão do partido, como instituição, ao abolicionismo. Por ocasião da palestra proferida por Campos Sales em Santos, em 1887 - no que deveria ser uma festa liberal em homenagem à memória de José Bonifácio (o moço) -, realizada na Ilha Porchat, Jardim interpelou o palestrante acerca da questão da abolição e exigiu um compromisso do partido com a causa, desafi-

sendo, ainda quando por ocasião da votação da Lei do Ventre Livre (1871) e da Lei dos Sexagenários (1885), um ferrenho opositor das medidas de caráter emancipacionista, acusando D. Pedro II de provocar a discórdia e agir de maneira a exceder o seu "poder pessoal". Mas, em 1888, era um defensor da abolição e foi responsável, segundo Evaristo de Moraes, pela redação da fala do trono de 1888, em que a regente Isabel apontava para a abolição (MORAES, 1986, p. 262-265).

15 A presença maciça de fazendeiros que perderam seus escravos nas fileiras do Partido Republicano é em parte responsável pelas interpretações da queda da monarquia como as de Oliveira Vianna, que vê na república uma "obra de ressentidos”. Cf. Vianna (1959) e Costa (1999). 
ando os republicanos a não aceitarem membros possuidores de escravos após data determinada pela agremiação. Campos Sales teve dificuldades, já que seria difícil empenhar sua palavra sem consulta aos outros membros do partido, mas comprometeu-se em lutar por isso. O resultado foi a circular que estabeleceu a obrigatoriedade dos republicanos paulistas em libertar seus escravos, além da adesão maciça de liberais santistas ao partido e a ascensão de Silva Jardim como propagandista republicano (SILVA JARDIM, 1891; CAMPOS SALES, 1983).

A circular não foi bem aceita pelos republicanos que possuíam escravos, já que contrariava as diretrizes da Comissão Permanente do PRP. Na província, cada vez mais a situação política tornava-se confusa, com republicanos, liberais e conservadores aglutinando-se em campos opostos a partir da idéia da abolição.

Quando por ocasião do governo provincial de Queirós Telles, conservador que teve a iniciativa da construção da hospedaria dos imigrantes e que tinha claras perspectivas abolicionistas, houve uma oposição ferrenha por parte dos fazendeiros de Campinas, republicanos que viam no novo governo uma aproximação perigosa com as senzalas.

Se em São Paulo, onde o partido era mais organizado, a situação era essa, no restante do país ela agravava-se. No Rio de Janeiro havia pouco espaço de atuação para o partido, sendo seus membros "flutuantes" entre o Partido Liberal e o Partido Republicano, o mesmo dando-se em Minas. No Rio de Janeiro havia o agravante da posição claramente majoritária do Partido Conservador que, no tocante à questão da abolição, conseguiu liderar tanto a iniciativa quanto a resistência à sua efetivação. Na Corte, o Partido Republicano assumia uma postura mais clara pelo abolicionismo e possuía uma militância urbana e influente na imprensa, mas pouco representativa em termos de densidade eleitoral. Nas províncias como Rio Grande do Sul e Pernambuco, os republicanos possuíam uma identidade mais diferenciada: na primeira claramente havia uma posição federalista muito forte e uma inclinação para apoiar a abolição e em Pernambuco havia um partido de forte inspiração positivista, sob a liderança de Aníbal Falcão.

O Partido Republicano era, sem dúvida, a instituição mais claramente favorável à mudança do regime, mas não era a única. A República estava no horizonte de grupos como os positivistas e, a partir de 1870, cada vez mais dos militares, principalmente os de baixa patente, e dos alunos e corpo docente da Escola Militar. Diferentemente do que ocorria com os quadros partidários propriamente ditos, dentre os positivistas e dentro do Exército o republicanismo tinha uma clara orientação abolicionista. Para seus defensores, não era possível conjuminar um regime político republicano com a manutenção da escravidão e, mais que isso, não era possível professar a fé republicana e possuir escravos ao mesmo tempo. Daí a desconfiança tanto de positivistas quanto de militares em relação ao Partido Republicano, em especial em relação aos chefes paulistas e fluminenses, que monopolizavam a direção central do partido.

Se os republicanos e os abolicionistas não podem ser associados diretamente, o mesmo não se pode dizer da República e da Abolição. Intimamente relacionadas, são o desfecho de um processo de mudança que vinha sendo gestado pelo menos desde 1870. Sem dúvida, uma parcela dos proprietários rurais foram jogados no movimento republicano, decepcionados com a Monarquia no episódio da abolição. Porém, é muito pouco supor a República como "obra de ressentidos". Os "ressentidos" fizeram parte do movimento, principalmente no final, mas não foram os responsáveis pela implantação do governo republicano. Apesar da fragilidade do partido - um pouco menor em São Paulo - o movimento republicano ganhou volume na década de 1880 com o crescimento da propaganda nos centros urbanos, com o apoio cada vez maior dos militares, com o crescimento de um "movimento de contestação" (ALONSO, 2000) e pela própria fragilidade do edifício imperial.

Nos dizeres de republicanos como Luís Gama e Silva Jardim, não seria possível dissociar a Abolição da República. No entanto, vimos que, na prática, isso ocorreu e, mais ainda, parte da inserção que o ideal republicano conseguiu dentro da elite brasileira foi graças a uma ambigüidade explícita em relação à questão abolicionista que manteve até as vésperas da Lei Áurea.

A questão é que a República de Jardim ou Gama não necessariamente era a República dos fazendeiros escravistas do PRP, por exemplo. Tributários das idéias iluministas francesas e ten- 
do como exemplo maior o regime político advindo da revolução de 1789, os republicanos "radicais", independentemente de suas diferenças, partiam do pressuposto da igualdade fundamental dos homens como base de construção do novo regime. Consideravam, como Rousseau, o atributo da liberdade um atributo do próprio ser humano.

Já a corrente majoritária de republicanos não via a abolição como uma necessidade intrínseca ao regime republicano. Isso porque seguiam, de alguma maneira, a trilha dos políticos imperiais que não viam problema em conjugar ideais liberais e a defesa da manutenção da escravidão. Como afirma Bosi, o liberalismo brasileiro, "parcial e seletivo, não era incongruente: operava a filtragem dos significados compatíveis com a liberdade intraoligárquica e descartava as conotações importunas, isto é, as exigências abstratas do liberalismo europeu que não se coadunassem com as particularidades da nova nação" (BOSI, 1993, p. 217).

A não-adesão integral dos republicanos ao ideal abolicionista provocou efeitos contraditórios sobre a agremiação partidária e sobre o próprio movimento. As suspeitas que passaram a pairar sobre os republicanos que não apoiavam a libertação dos escravos, sendo depositários da fúria de organizações como a Guarda Negra, introduziram mais um elemento de confusão dentro do cenário político nacional. Como afirmava Joaquim Nabuco, a questão abolicionista transcendeu os partidos e extravasou a política. Mas, mesmo os defensores da abolição, salvo raras exceções como André Rebouças, também moviam-se no mesmo terreno de seus detratores: não era a liberdade pessoal que estava em jogo, mas a necessidade de modernizar o país e possibilitar a construção nacional. Nos dizeres de José Murilo de Carvalho, era a razão nacional que presidia o debate, não a razão individual. É por isso, segundo ele, que "consumada a abolição, nada foi feito em benefício dos ex-escravos. O progresso do indivíduo era secundário" (CARVALHO, 1998, p. 63).

\section{CONSIDERAÇÕES FINAIS}

A forma pela qual a abolição da escravidão foi efetivada "jogou" nas hostes republicanas uma série de elementos conservadores - que foram úteis e necessários - que, de alguma maneira, provocaram uma "correção de rota" no movimento. A centralidade do papel da Coroa na emancipação final dos escravos provocou, como vimos anteriormente, uma confusão não só no quadro parti- dário imperial, mas também republicano. Mais do que isso separou o par República-Abolição, que era crucial dentro da linha de argumentação de uma série de republicanos, justamente aqueles que propunham mudanças mais substantivas que não a mera alteração da forma de governo. A trajetória da dupla Patrocínio-Jardim parece ser o exemplo máximo desse tipo de problema. Na separação, cada um ficou com um dos termos da equação, transformando-o em bandeira, buscando aliados em campos opostos e exagerando na argumentação tanto em defesa quanto em ataque aos oponentes. A República de Jardim ficou órfã da Abolição, enquanto a Monarquia de Patrocínio ganhou salvo-conduto por conta da Abolição.

O republicanismo de membros mais radicais, como Silva Jardim, após o 13 de Maio, empobreceu. A dimensão da crítica social e a busca pela superação da ordem econômica e social ficaram escondidas em meio a um discurso retórico e de ataques à Monarquia feitos sob medida para uma platéia desejosa de ouvir exatamente o que ele falava. Ao privilegiar esses interlocutores, o próprio Jardim apartou-se daquele público que deveria ser o seu alvo: as classes pobres urbanas. Após o 13 de Maio, boa parte dessas classes pobres urbanas era-lhe hostil: em especial o proletariado do Rio de Janeiro, engrossado pelos ex-escravos. O discurso revolucionário - quando aparecia - caía no vazio de uma revolução sem povo, nos ouvidos de um grupo social que não queria nem a revolução nem a participação popular. De certa maneira, a condução da abolição pela Coroa inviabilizou não só a Monarquia, mas também uma República de caráter mais popular. Os republicanos herdaram um país onde a grande questão - a abolição da escravidão - já estava resolvida. É verdade que, depois da abolição, nada foi feito em termos de políticas sociais voltadas ao segmento dos ex-escravos. No entanto, isto também não era "culpa" dos republicanos. Mais uma vez o fardo poderia ser jogado nas costas da Monarquia, que empreendeu uma obra inconclusa. Não seria justo impor o ônus da resolução do problema aos republicanos. Com a abolição resolvida, era possível aos novos donos do poder fazer tábua rasa do passado. A nova era deveria começar sem dívidas com o passado. Além disso, com a questão solucionada, não mais se sofreria com a cisão oriunda de posições diferentes. Havia a possibilidade de se proceder a uma conciliação entre diversas correntes republicanas com a questão resolvida. Só 
que o modelo de conciliação era justamente o modelo defendido por um grupo republicano aquele que se encontrava sob a bandeira do Partido Republicano - e que levou à instituição de fato do novo regime, modelo esse que também era o do Império, principalmente após a traumática experiência da regência.

A opção por uma ação política que deliberadamente negava a discussão da principal reforma social e econômica do país, de certa maneira, contribuiu para condicionar a futura República. A perspectiva de empurrar para frente no tempo uma discussão maior acerca da inserção dos ex-escravos na sociedade brasileira acabou por contribuir para a manutenção da ordem social e econômica do Império. Ao mesmo tempo, o movimento abolicionista, dissociado dos próprios escravos, reforçou o caráter meramente formal da abolição ${ }^{16}$. A solução política apontada para a abolição e seus desdobramentos contribuíram para a formatação da República oligárquica, justamente porque a abolição em 1888 tirou a responsabilidade dos republicanos frente ao passado. Mesmo dos republicanos mais radicais, abolicionistas. Separados de seu diferencial, perderam-se em meio ao movimento capitaneado pela elite proprietária do centro-sul. Se havia uma preocupação mais republicana por parte de alguns elementos do movimento de contestação ao Império, essa se perdeu em meio às mudanças operadas após o fim da escravidão.

Mas, mesmo depois disso, ainda havia uma brecha. Ao longo da primeira década republicana, havia ainda a possibilidade de mudanças mais substanciais virem na esteira do movimento de implantação da República. A “janela” foi-se fechando graças às sucessivas derrotas dos projetos alternativos, projetos estes que possuíam uma ancoragem clara no Estado. Tomando-se o caso dos jacobinos, fica claro o recurso ao Estado como agente promotor do desenvolvimento e a necessidade da manutenção das estruturas centralizadas. Assim como seus pares mais conservadores, os

16 Como aponta Luiz Felipe Alencastro, "au Brésil les secteurs progressistes condamnent l'esclavage mais n'appellent pas les esclaves à la revolte. On plaint l'esclave, on ne s'en identifie pas. La rupture culturelle existant entre les esclaves et les autres couches sociales joue un rôle de repoussoir et conduit l'intelligentsia brésilienne à chercher à modernizer l'État pour em farie l'instrument de l'évolution sociale" (ALENCASTRO, 1983, p. 309). republicanos mais radicais viam a construção da cidadania como construção da "estadania" (CARVALHO, 2001). O vago povo mobilizado não poderia mobilizar-se tanto assim, mesmo nessa concepção republicana.

A mesma percepção da centralidade do papel do Estado na construção do novo regime era compartilhada pelos republicanos mais conservadores. Os desdobramentos da implantação da República na última década do século XIX geraram a crença na necessidade de se reavivar o controle central por um equivalente funcional do poder moderador. Por oposição à situação real que se enfrentava, a decantada estabilidade imperial moldou o universo mental da elite republicana. A centralidade do Estado imperial na manutenção do território nacional e a experiência traumática da Regência fizeram com que os republicanos adotassem a mística do Império como real. Tratava-se de adequar um novo desenho institucional a um Estado que deveria ser tão sólido quanto o anterior. $\mathrm{O}$ medo da dissolução federal fez com que os republicanos transigissem com parcelas da elite imperial e as absorvessem num novo desenho. Quaisquer vôos mais altos deveriam ser abortados. Para os republicanos da década de 1890 , tratava-se de encontrar um equilíbrio entre a mudança e a ordem, mas a opção foi mais pela ordem. Os resultados determinaram o abandono de fórmulas mais democráticas de organização política (LESSA, 1988).

A modernização intentada reduzia-se ao Estado e ao seu acabamento institucional. A República desejada e desenhada vinha desacompanhada do espírito republicano, cívico, de seu aspecto democrático. As alianças empreendidas pelos republicanos mais radicais com setores ligados à lavoura escravista inviabilizaram a construção de um arco de alianças com setores mais populares e tornaram a alternativa republicana, na sua acepção mais completa, frágil. A estratégia adotada por esses republicanos acabou por reforçar a exclusão e a concepção dos setores populares como "classes perigosas"17. Ao mesmo tempo, o controle e a absorção por parte da elite dos republica-

\footnotetext{
17 O próprio Jardim acusava os seus opositores de serem perigosos e manipulados pela Monarquia, vendo com desconfiança os ex-escravos, muitos dos quais supunham "ter o direito de não trabalhar, mas de serem sustentados por seus antigos senhores" (SILVA JARDIM, 1891, p. 293).
} 
nos de sua parcela mais radical, restringindo e disciplinando sua ação, possibilitaram o fortalecimento de um republicanismo conservador que manteria inalterada a estrutura socioeconômica do país. Gradativamente, as alternativas ao modelo hegemônico foram sendo suprimidas, com o fechamento da "janela" aberta a partir de 1889. Como afirmam Werneck Vianna e Carvalho (2000), a Primeira República não empreendeu a obra de promover o avanço do liberalismo no país, principalmente na construção dos direitos civis. O liberalismo "cristalizou-se como ideologia das elites, sem desenvolver as suas potencialidades universalistas [...] frustrando as expectativas de uma plena passagem do país a uma ordem social competitiva" (WERNECK VIANNA \& CARVALHO, 2000, p. 24).

Se a República poderia ter outra história, não sabemos. Mas acreditamos que parte do resultado político que foi obtido na Primeira República foi fruto da ação de republicanos que não necessariamente concordavam com ele. A chave para isso, acreditamos, encontra-se na dissociação entre República e Abolição, dissociação esta moldada pela própria Monarquia, mas acolhida como uma opção racional por muitos republicanos. Esta é uma questão central: a ação da Monarquia contribuiu para a formação de um Partido Republicano de caráter e conteúdo conservador e oligárquico. A ação dos republicanos radicais, por sua vez, acabou por reforçar esse caráter e esse conteúdo, tanto do Partido quanto da República que nasce em 1889 (mas principalmente a partir de 1898).

Não tarda a grassar entre os republicanos, notadamente entre aqueles que propunham mudanças mais radicais, um sentimento de desencanto com o novo regime. O desencanto é um lado da moeda, o outro é o estranhamento. O que os republicanos mais radicais não entendiam - o que pode ser exemplificado pelos jacobinos em relação a Canudos - é como a população brasileira mostrava-se alheia aos progressos prometidos pelo regime republicano. A razão estava com eles, logo o povo ou era ignorante ou mal-intencionado. Mais ainda, talvez o problema do Brasil estivesse justamente na falta de um povo propriamente dito. Não havia no país solidariedade ou mesmo uma idéia de comunidade nacional, daí a população poder ser manipulada como massa de manobra de setores oligárquicos. À República, dessa maneira, caberia mais uma tarefa: a própria construção da nacionalidade.

A obra republicana deveria ir além e criar o próprio povo brasileiro. No entanto, não parecia ser esse o caminho inaugurado pelo novo regime de 1889. Do estranhamento ao desencanto, foi rápido o caminho percorrido pelos republicanos.

Maria Fernanda Lombardi Fernandes (felombardi@uol.com.br) é Doutora em Ciência Política pela Universidade de São Paulo (USP) e Professora de Ciência Política da Universidade Federal de São Paulo (UNIFESP).

\section{REFERÊNCIAS BIBLIOGRÁFICAS}

ALENCASTRO, L. F. 1979. La traite negrière et l'unité brésilienne. Revue Française d'Histoire d'Outre-Mer, Saint-Denis, t. LXVI, n. 244245 , p. 395-419.

1983. L'Empire du Brésil. In : DUVERGER, M. (org.). Le Concept de l'Empire. Paris : PUF.

ALONSO, A. M. 2000. Idéias em movimento : a geração 70 na crise do Brasil-Império. São Paulo. Tese (Doutorado em Sociologia). Universidade de São Paulo.
BOEHRER, G. C. 1954. Da Monarquia à República : história do Partido Republicano do Brasil (1870-1889). Rio de Janeiro : Ministério da Educação e da Cultura.

BOSI, A. 1993. Dialética da colonização. São Paulo : Companhia das Letras.

CAMPOS SALES, M. F. 1983. Da propaganda à presidência. Brasília : UNB.

CARVALHO, J. M. 1996. Apresentação. In : PATROCÍNIO, J. Campanha abolicionista : coletânea de artigos. Rio de Janeiro : Fundação Biblioteca Nacional. 
1998. Pontos e bordados : escritos de História e Política. Belo Horizonte : UFMG.

2001. Cidadania no Brasil : o longo caminho. Rio de Janeiro : Civilização Brasileira.

CASTRO, C. 1995. Os militares e a República. Rio de Janeiro : J. Zahar.

CHALHOUB, S. 2001. Visões da liberdade : uma história das últimas décadas de escravidão na Corte. São Paulo : Companhia das Letras.

COSTA, E. V. 1999. Da Monarquia à Repúbli$c a$ : momentos decisivos. São Paulo : UNESP.

FERNANDES, M. F. L. 2004 A esperança e o desencanto : Silva Jardim e a República. São Paulo. Tese (Doutorado em Ciência Política). Universidade de São Paulo.

LIMA, H. F. 1987 Perfil político de Silva Jardim. Col. "Brasiliana". São Paulo : Nacional.

HOLANDA, S. B. 1985. História Geral da Civilização Brasileira. T. II : O Brasil monárquico. V. 5 : Do Império à República. São Paulo : Difel.

KUGELMAS, E. 1986. Dificil hegemonia : um estudo sobre São Paulo na Primeira República. São Paulo. Tese (Doutorado em Ciência Política). USP.

LACOMBE, A. J.; SILVA, E. \& BARBOSA, F. A. 1988. Rui Barbosa e a queima de arquivos. Rio de Janeiro : Fundação Casa de Rui Barbosa

LEITE, S. F. 1993 A República no Brasil : Quintino Bocaiúva e Silva Jardim - trajetórias e idéias. São Paulo. Dissertação (Mestrado em História Social). Universidade de São Paulo.
LESSA, R. 1988. A invenção republicana : Campos Sales, as bases e a decadência da Primeira República brasileira. Rio de Janeiro : Vértice.

MACHADO, M. H. 1994. O plano e o pânico : os movimentos sociais na década da abolição. Rio de Janeiro : UFRJ.

MATTOS, H. M. 2004. Escravidão e cidadania no Brasil monárquico. Rio de Janeiro : J. Zahar.

MORAES, E. 1986. A campanha abolicionista (1879-1888). Brasília : UNB.

NABUCO, J. 1988. O abolicionismo. Petrópolis : Vozes.

VIANNA, F. J. O. 1959. O occaso do Império. Rio de Janeiro : J. Olympio.

PESSOA, R. C. 1973. A idéia republicana através dos documentos. São Paulo : Alfa-Ômega.

QUEIROZ, M. V. 1967. Paixão e morte de Silva Jardim. Col. "Retratos do Brasil". Rio de Janeiro : Civilização Brasileira.

SANTOS, J. M. 1942. Os republicanos paulistas e a Abolição. São Paulo : Martins.

SILVA, A. R. C. 1999. Construção da nação e escravidão no pensamento de José Bonifácio (1783-1823). Campinas : UNICAMP.

SILVA, E. 1986. Introdução. In : Idéias políticas de Quintino Bocaiúva. Brasília : Senado Federal.

SILVA JARDIM, A. 1891. Memórias e viagens : campanha de um propagandista. Lisboa : Nacional.

VIANNA, L. W. \& REZENDE, M. A. 2000. República e civilização brasileira. Estudos de Sociologia, Araraquara, v. 8, p. 7-33. 